\title{
The Albanian Mutual Funds during the COVID pandemic
}

\author{
Brian Balliu
}

UDC 336.76]:616.98:578.834\}-036.21(496.5)

SNSPA, PoverneiStr. Povernei, 6, București, Romania

brian.balliu.20@drd.snspa.ro

\begin{abstract}
The COVID-19 pandemic caused a lockdown of a global scale and subsequent enforcement of it had an impact in the capital markets, and the Albanian mutual fund industry would not remain an exception. Such crisis put the industry into an unprecedented stress test. This paper uses qualitative research method to identify the challenges that were faced by the mutual fund industry during the beginning of the pandemic. This includes the fund flow perspective, secondary debt markets, the shifts of regulations and the behavior of investors. The conclusions that will be drawn from this study are aimed to help capital market investors and researchers in drawing strategies in the Albanian market during crisis times. Albania is recognized as an emerging economy and during its ongoing stage of development, the COVID-19 pandemic caused turbulences in the economic stability of the country. With many measures put in motion in order to reduce the impact of the pandemic upon the population, all the sections of the economy have been facing disruption. The capital market, likewise, was met with a lot of challenges during this period. Although, history has shown that the Mutual Fund (MF) industry has always bounced back significantly after taking a hit. Considering the impact of the crisis, the regulator, Financial Supervisory Authority (FSA), closely supervised the liquidity to ensure the mutual funds would be able to operate in stressful conditions and in the best interest of the investor. For this study, a Qualitative research method is applied by using Histographical research approach, regarding the past and present events that are associated with the Albanian Mutual Fund Industry. Furthermore, data from regulator websites, company websites, business newspapers in physical and digital forms are used in the study as well as research papers. Moreover, data from financial statements of the Mutual Funds (MFs) has been sourced from the websites of Asset Management Companies (AMCs).
\end{abstract}

Keywords: Mutual Funds, Investor behavior, COVID, Finance, Albania

\section{Introduction}

Albania is recognized as an emerging economy and during its ongoing stage of development, the COVID-19 pandemic caused turbulences in the economic stability of the country. With many measures put in motion in order to reduce the impact of the pandemic upon the population, all the sections of the economy have been facing disruption. The capital market, likewise, was met with a lot of challenges during this period. Although, history has shown that the Mutual Fund industry has always bounced back significantly after taking a hit. Considering the impact of the 
crisis, the regulator, Financial Supervisory Authority (FSA), closely supervised the liquidity to ensure the mutual funds would be able to operate in stressful conditions and in the best interest of the investor.

\section{Macroeconomic Outlook}

The Albanian economy was struck hard by the COVID-19 pandemic, because of its major dependance on tourism and remittances [1]. Furthermore, the November 2019 earthquake took an additional toll on the economic activity, and this sent the fiscal deficit projections to rise to $7 \%$ of the GDP followed by the public debt to slightly $80 \%$ of the GDP by the end of 2020 [1]. The tourism which accounts for $20 \%$ of Albania's GDP [2], was one of the most affected sectors by the pandemic. In the end of July 2020, the number of foreign tourists was reported to have decreased by $61.5 \%$ compared to the previous year [3]. Moreover, a loss of 34000 jobs and an increase of the unemployment rate by 0.6 pps y-o-y to $12.5 \%$ [4], evidenced a deuteriation of the labor market in Albania. The Albanian Lek depreciated by almost $7 \%$ at the beginning of the pandemic. However, the currency has since strengthened, and it sat at $1.9 \%$ above the last year's annual average of 2019. Nonetheless, the initial depreciation against EUR combined with a strong increase in food prices caused the CPI inflation to rise from 1.4\% in 2019 to $1.9 \%$ in the second quarter of 2020 but decreased again to $1.1 \%$ by the end of 2020 [4]. The recession was first driven by a contraction in investment, private and public consumption, as well as a large fall in exports by $35 \%$ [5]. However, the recession slowed down due to an increase in investment growth by $4.1 \%$ y-o-y [4]. This was as a result of construction projects in the aftermath of the earthquake.

\section{Mutual Fund Industry}

The Albanian Mutual Fund industry started its activity back in 2012 [6] with the newly appointed regulations by the FSA and in recent years it has seen many new companies joining the market and offering Mutual Funds of different asset classes. The majority of the Mutual Funds has a portfolio comprised of securities that are issued by the Albanian Government, with only Raiffeisen EURO and WVP Top Invest, investing in Foreign Bonds and the latter in Stocks. Except for AlbSig Invest and WVP Invest, all other companies work as subsidiaries of a second level bank and hence are supported by them.

Table 1 AMCs and Mutual Funds active in 2020

\begin{tabular}{|l|l|l|l|}
\hline AMC & Mutual Fund & Asset Structure & Currency \\
\hline Raiffeisen Invest & Raiffeisen Prestigj & Albanian Gov. Securities & ALL \\
\hline & Raiffeisen EURO & European Bonds & EUR \\
\hline & Raiffeisen Vizion & Albanian Gov. Securities & ALL \\
\hline Credins Invest & Credins Premium & Albanian Gov. Securities & ALL \\
\hline AlbSig Invest & AlbSig Standard & Albanian Gov. Securities & ALL \\
\hline WVP & Top Invest & Equities & ALL \\
\hline
\end{tabular}

\section{Fund Capital Outflows}


Since the inception of the first two investment funds by Raiffeisen Invest, the confidence of the investors has seen a rise, especially in the recent years with an increase in the number of investment schemes offered by different Asset Management Companies. However, there is no evidence or found records of capital inflow, and the investment is assumed to be done through local investors.

\section{First Impact}

With the risk propagating the markets, uncertainty for the future and fears of corporate defaults made the investors rush to redeem their mutual fund shares. Due to this, AMCs experienced a liquidity squeeze and had to resort on selling securities held by investment schemes in order to cover the redemption pressure and obtain the required liquidity levels. However, for each scheme the impact was different depending on the asset classes the portfolio was made of. The mutual funds that had exposure to international markets were subject to a bigger dip in their unit price, compared to the mutual funds that invested in securities backed by the Albanian Government. Even before the COVID-19 pandemic, The Albanian market had sound levels of liquidity [7], which made it easier for fund managers to trade securities in order to cover the outflows and maintain surplus cash positions when necessary. The trend on new mutual fund launches came down in 2020 compared to previous years. However, the trend would resume by the end of the fourth quarter of 2020 with 3 new investment funds getting licensed by the FSA [8].

\section{Government}

Considering the dire situation created by the COVID-19 pandemic. On 25 $5^{\text {th }}$ of March 2020 Bank of Albania took measures to mitigate the negative effects of the pandemic by keeping the interest rates lower for loans, providing favorable exchange rates and injecting liquidity by offering unlimited borrowing with a $0.5 \%$ interest rate to the banks [9]. Although the measures taken by the Bank of Albania did not benefit the MFs directly, they would prove useful for investment funds that were sponsored by banks, as it opened an opportunity to cover for the unit outflows. The Financial Supervisory Authority, which is the main regulator for the MFI took a lighter approach by requesting daily reports on the liquidity ratios for each investments scheme under management by the AMCs [10]. Despite the large number of outflows, AMCs managed to maintain the liquidity by trading securities from the portfolios of the Funds. During this period, none of the investment funds was deemed as insolvent and all of them kept the operations ongoing. It should be noted that no other measures like liquidity injection was carried by the FSA during this period.

\section{Investor Behavior}

During a crisis, investors tend to get tense when their investments go down. In previous occasions when a crisis struck, AMCs were met as investors not only stopped their SIP (Systematic Investment Plan), but a major part withdrew their investments due to the fear of the pandemic lasting for a longer than anticipated time [11]. Such situation creates panic, which is followed by short-term volatility. Analyzing statistics that are published by the FSA, there was seen a small drop in MF investments when comparing the first quarters of 2019 and 2020 [12]. However, the number of memberships saw growth by $6.98 \%$ when comparing data from the third quarters of 2019 and 2020 [12]. By analyzing the financial statements of the MFs, there are changes in the assets, hinting to trade activity during the initial phase of the COVID-19 pandemic. Considering the reduced return rate during this period and a fall in the value of unit price for all the MFs. We can assume the fund managers were rushing to trade securities in 
order to cover for liquidity needs due to a higher than anticipated number of redemptions from investors.

\section{Performance}

The pandemic created an unprecedented event for the capital markets around the world and the Albanian MF Industry was no exclusion. Faced with a huge number of redemptions and rising interest rates, the AMCs had to think quickly in order to remain active. However, considering the aforementioned, the negative impact on funds performance was inevitable. The Bank of Albania, rose the interest rates which caused a depreciation in value on the assets that were on the portfolios of the funds. Combined with the pressure that was caused by the high rates of redemptions, fund managers had to trade the securities at lower prices so they could cover the liquidity squeeze. This caused a drop in the unit prices and Net Asset Value (NAV) of the funds. Comparing the unit price movements between the 3 biggest funds that are denominated in the local currency (ALL), we could se that the downfall and recovery trend is quite similar between them. However, when compared to WVP Top Invest that has exposure to equity markets and Raiffeisen Euro with exposure to European bonds, it is evident that the unit price of both funds experienced a bigger fall. For funds with an asset allocation in Albanian Government securities, the maximum drawdown was reached during the month of April 2020, Raiffeisen Euro however reached it during May 2020 and due to its equity exposed portfolio, WVP Top Invest was the first to hit its maximum drawdown during March 2020. AlbSig Standard, a mutual fund that started its activity in the first quarter of the 2020, remained in a negative return rate for the year from its subscription period price to December $31^{\text {st }} 2020$.
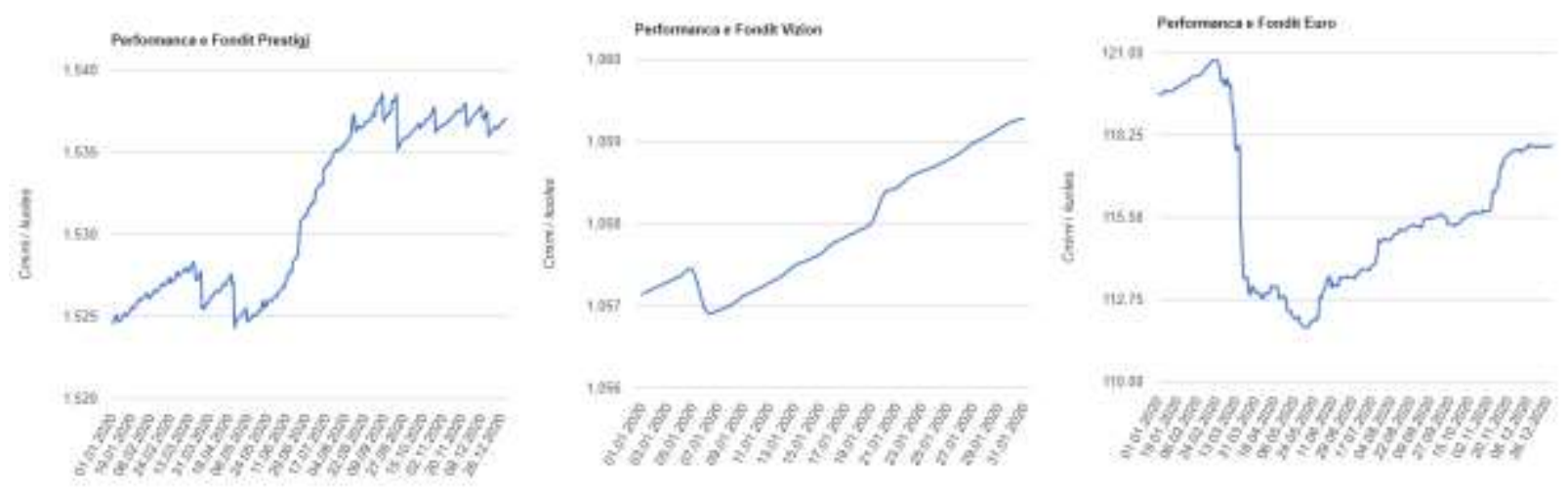

Figure 1 Performance data for Raiffeisen Prestigj, Vizion and Euro respectively [13] 


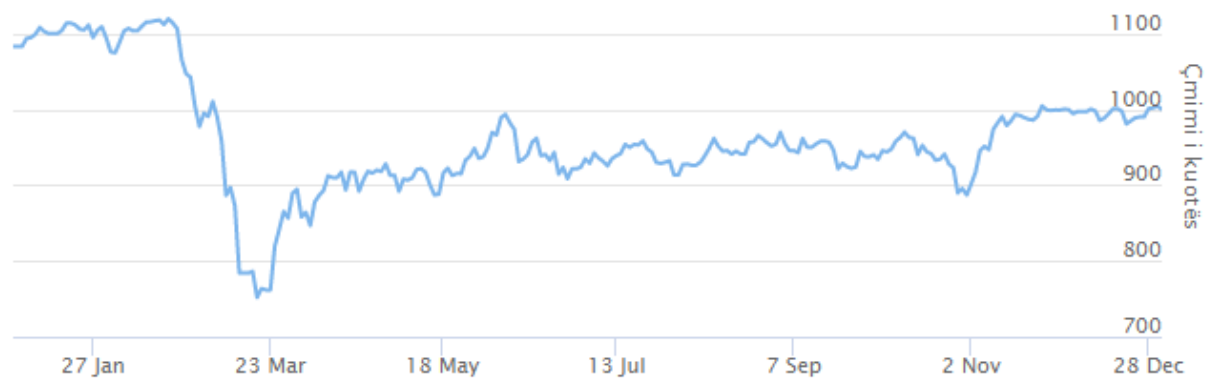

Figure 2 Performance data for WVP Top Invest [14]

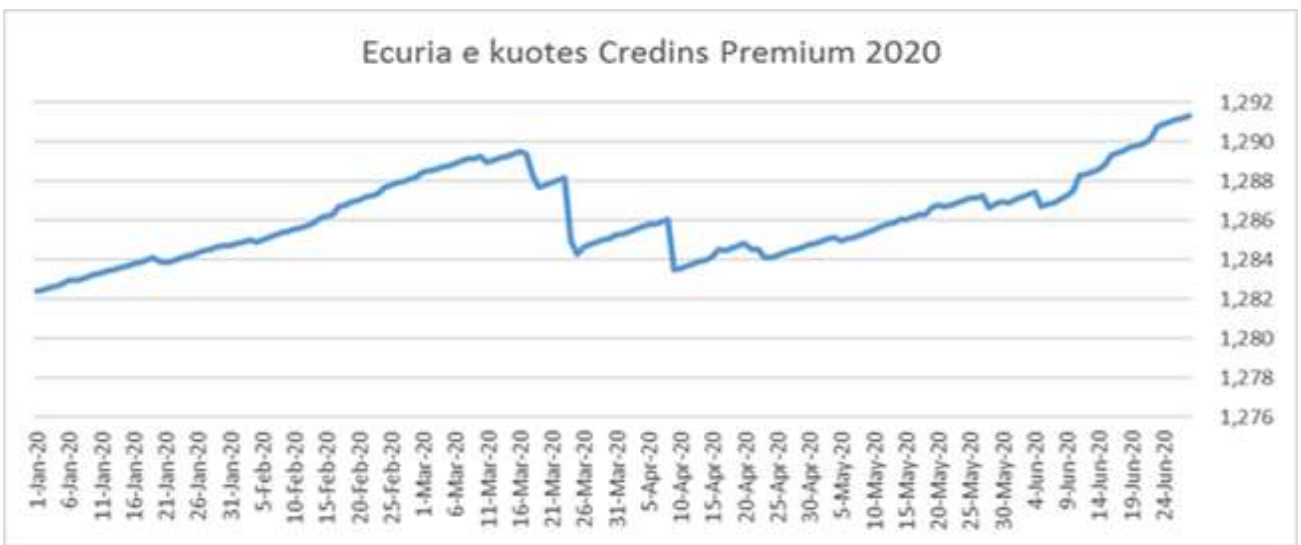

Figure 3 Performance data for Credins Premium [15]

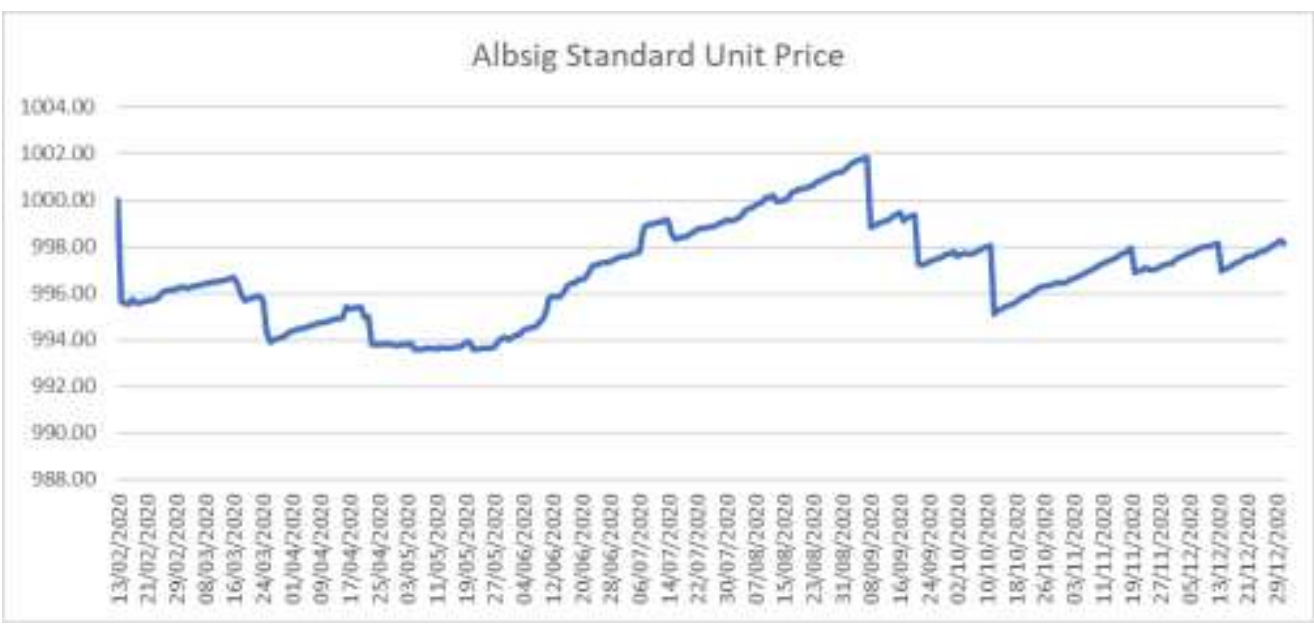

Figure 4 Performance data for AlbSig Standard [16] 


\section{Rebound}

Despite the dire situation and the dip experienced by the MFs, recovery began quite quickly. For the funds with an asset allocation in Albanian Government securities, the unit price recovered quite quickly to pre-pandemic levels and continued to increase through the year, ending 2020 with profits for investors that did not redeem their units or the investors that benefited from the opportunity of purchasing units at a lower price during the fall. Nonetheless, the investor confidence began to rise during the third quarter of 2020 with an increased number of inflows in mutual funds [17]. The same trend followed also for Raiffeisen Euro and WVP Top Invest of which the upside was also higher than the one experienced by the other mutual funds. Despite the negative outlook of the economy, the MF industry continued to grow and during the fourth quarter of the 2020, FSA licensed 3 more mutual funds. Moreover, during the beginning of the second quarter of 2021 the interest rates began to fall [18] and mutual funds that had their asset allocation in Albanian Government securities experienced an increase in the unit price due to the appreciation in value of the assets that were acquired during the 2020 or early 2021 . A fall in the interest paid on deposits offered by banks also contributed to an increase in inflows for mutual funds as investors started seeking more profitable alternatives.

Table 2 Profitability of Credins Premium

\begin{tabular}{|c|c|c|c|c|c|c|c|c|}
\hline From & to & $\begin{array}{c}3 \text { Month } \\
\text { Profitability } \\
\text { in \% }\end{array}$ & $\begin{array}{c}31 / 03 / 18 \\
- \\
31 / 03 / 19 \\
\end{array}$ & $\begin{array}{c}30 / 06 / 18 \\
- \\
30 / 06 / 19 \\
\end{array}$ & $\begin{array}{c}30 / 09 / 18 \\
- \\
30 / 09 / 19 \\
\end{array}$ & $\begin{array}{c}31 / 12 / 18 \\
- \\
31 / 12 / 19\end{array}$ & $\begin{array}{c}31 / 03 / 19 \\
- \\
31 / 03 / 20 \\
\end{array}$ & $\begin{array}{c}28 / 06 / 19 \\
- \\
28 / 06 / 20 \\
\end{array}$ \\
\hline $31 / 03 / 2018$ & $30 / 06 / 2018$ & $1.6 \%$ & \multirow{4}{*}{$\begin{array}{c}\text { Annualized } \\
10.7 \%\end{array}$} & \multirow{5}{*}{$\begin{array}{c}\text { Annualized } \\
8.5 \%\end{array}$} & \multirow{6}{*}{$\begin{array}{c}\text { Annualized } \\
6.3 \%\end{array}$} & \multirow{7}{*}{$\begin{array}{c}\text { Annualized } \\
5.2 \%\end{array}$} & \multirow{8}{*}{$\begin{array}{c}\text { Annualized } \\
0.7 \%\end{array}$} & \\
\hline $30 / 06 / 2018$ & $30 / 09 / 2018$ & $2.0 \%$ & & & & & & \\
\hline $30 / 09 / 2018$ & $31 / 12 / 2018$ & $2.0 \%$ & & & & & & \\
\hline $31 / 12 / 2018$ & $31 / 03 / 2019$ & $4.7 \%$ & & & & & & \\
\hline $31 / 03 / 2019$ & $30 / 06 / 2019$ & $-0.4 \%$ & & & & & & \\
\hline $30 / 06 / 2019$ & $30 / 09 / 2019$ & $-0.1 \%$ & & & & & & \multirow{4}{*}{$\begin{array}{c}\text { Annualized } \\
1.6 \%\end{array}$} \\
\hline $30 / 09 / 2019$ & $31 / 12 / 2019$ & $1.0 \%$ & & & & & & \\
\hline $31 / 12 / 2019$ & $31 / 03 / 2020$ & $0.2 \%$ & & & & & & \\
\hline $31 / 03 / 2020$ & $30 / 06 / 2020$ & $0.5 \%$ & & & & & & \\
\hline
\end{tabular}

Table 3 Profitability Raiffeisen Prestigj

\begin{tabular}{|c|c|c|c|c|c|c|c|c|}
\hline From & to & $\begin{array}{l}3 \text { Month } \\
\text { Profitability } \\
\text { in } \%\end{array}$ & $\begin{array}{c}31 / 03 / 18 \\
- \\
31 / 03 / 19\end{array}$ & $\begin{array}{c}30 / 06 / 18 \\
- \\
30 / 06 / 19\end{array}$ & $\begin{array}{c}30 / 09 / 18 \\
- \\
30 / 09 / 19\end{array}$ & $\begin{array}{c}31 / 12 / 18 \\
- \\
31 / 12 / 19\end{array}$ & $\begin{array}{c}31 / 03 / 19 \\
- \\
31 / 03 / 20\end{array}$ & $\begin{array}{c}28 / 06 / 19 \\
- \\
28 / 06 / 20\end{array}$ \\
\hline $31 / 03 / 2018$ & $30 / 06 / 2018$ & $1.1 \%$ & \multirow{2}{*}{$\begin{array}{c}\text { Annualized } \\
5.7 \%\end{array}$} & & & & & \\
\hline $30 / 06 / 2018$ & $30 / 09 / 2018$ & $1.3 \%$ & & Annualized & & & & \\
\hline
\end{tabular}




\begin{tabular}{|c|c|c|c|c|c|c|c|}
\hline $30 / 09 / 2018$ & $31 / 12 / 2018$ & $1.4 \%$ & \multirow[t]{3}{*}{$4.2 \%$} & \multirow{4}{*}{$\begin{array}{c}\text { Annualized } \\
2.5 \%\end{array}$} & & & \\
\hline $31 / 12 / 2018$ & $31 / 03 / 2019$ & $1.8 \%$ & & & \multirow{4}{*}{$\begin{array}{c}\text { Annualized } \\
1.9 \%\end{array}$} & & \\
\hline $31 / 03 / 2019$ & $30 / 06 / 2019$ & $-0.3 \%$ & & & & \multirow{4}{*}{$\begin{array}{c}\text { Annualized } \\
0.2 \%\end{array}$} & \\
\hline $30 / 06 / 2019$ & $30 / 09 / 2019$ & $-0.4 \%$ & & & & & \multirow{4}{*}{$\begin{array}{c}\text { Annualized } \\
0.9 \%\end{array}$} \\
\hline $30 / 09 / 2019$ & $31 / 12 / 2019$ & $0.8 \%$ & & & & & \\
\hline $31 / 12 / 2019$ & $31 / 03 / 2020$ & $0.1 \%$ & & & & & \\
\hline $31 / 03 / 2020$ & $30 / 06 / 2020$ & $0.4 \%$ & & & & & \\
\hline
\end{tabular}

Table 4 Profitability Raiffeisen Vizion

\begin{tabular}{|c|c|c|c|c|c|c|}
\hline From & to & $\begin{array}{c}3 \text { Month } \\
\text { Profitability in \% }\end{array}$ & $\begin{array}{c}30 / 09 / 18- \\
30 / 09 / 19\end{array}$ & $\begin{array}{c}31 / 12 / 18- \\
31 / 12 / 19\end{array}$ & $\begin{array}{l}31 / 03 / 19- \\
31 / 03 / 20\end{array}$ & $\begin{array}{l}30 / 06 / 19- \\
30 / 06 / 20\end{array}$ \\
\hline $30 / 09 / 2018$ & $31 / 12 / 2018$ & $2.0 \%$ & \multirow{4}{*}{$\begin{array}{c}\text { Annualized } \\
4.7 \%\end{array}$} & & & \\
\hline $31 / 12 / 2018$ & $31 / 03 / 2019$ & $2.6 \%$ & & \multirow{4}{*}{$\begin{array}{c}\text { Annualized } \\
3.9 \%\end{array}$} & & \\
\hline $31 / 03 / 2019$ & $30 / 06 / 2019$ & $0.1 \%$ & & & \multirow{4}{*}{$\begin{array}{c}\text { Annualized } \\
1.6 \%\end{array}$} & \\
\hline $30 / 06 / 2019$ & $30 / 09 / 2019$ & $0.0 \%$ & & & & \multirow{4}{*}{$\begin{array}{c}\text { Annualized } \\
2.1 \%\end{array}$} \\
\hline $30 / 09 / 2019$ & $31 / 12 / 2019$ & $1.2 \%$ & & & & \\
\hline $31 / 12 / 2019$ & $31 / 03 / 2020$ & $0.4 \%$ & & & & \\
\hline $31 / 03 / 2020$ & $30 / 06 / 2020$ & $0.6 \%$ & & & & \\
\hline
\end{tabular}

The tables above show the three biggest mutual funds that are denominated in ALL and their profitability between quarters. As it is shown, the three of them follow the same trend and return to increased profitability by the end of the second quarter of 2020 . The beforementioned tables were constructed using financial statement data from Credins Invest [19] and Raiffeisen Invest [20].

\section{Conclusion}

The mutual fund industry was doing pretty well before the pandemic hit. Over the years, the number of AMCs providing mutual funds for investors has been increasing due to the demand for financial products that offer higher rates of returns than bank deposits. However, the trend experienced a slowdown during 2020. Investors always tend to seek safe return during economic shocks. Yet, all mutual funds despite of their asset classes, experienced increased outflows from investors. It should be noted that during the pandemic, despite the grim situation, none of the AMCs filed for insolvency, which helped restore investor confidence quite quickly in the system. By the third quarter of 2020, all mutual funds had rebounded, and AMCs also managed to license new mutual funds by the end of the year. However, AMCs should focus more on investor education and their investment goals. It would have been quite useful during the early stages of the lockdown as it would have avoided the premature mass redemptions. 


\section{References:}

1. IMF Statistics Albania for 2020

https://www.imf.org/en/News/Articles/2020/09/28/mcs092820-albania-staff-concluding-

statement-of-the-first-post-program-monitoring-mission

2. OECD, Crisis Response SEE Report, 2020

https://www.oecd.org/coronavirus/policy-responses/covid-19-crisis-response-in-south-east-

european-economies-c1aacb5a/

3. INSTAT, Foreigners Movement Report, 2020

http://www.instat.gov.al/al/temat/industria-tregtia-dhe-shërbimet/turizmi/publikimet/2020/lëviziet-

e-shtetasve-korrik-2020/

4. European Commission, CCEQ Report, Q4 2020

https://ec.europa.eu/info/sites/default/files/economy-finance/tp046 en.pdf

5. IMF, World Economic Outlook, 2021

https://www.imf.org/en/Publications/WEO/weo-database

6. (AMF, Brief History, nd)

https://amf.gov.al/pershkrim.asp?id=1

7. Bank of Albania, Periodic Report, Q4 2019

https://www.bankofalbania.org/rc/doc/RPM 2019 IV shaip shtojca 15970.pdf

8. AMF, Board Decision $29^{\text {th }}$ Dec, 2020

https://amf.gov.al/news.asp?id=32639

9. Bank of Albania, COVID-19, 2020

https://www.bankofalbania.org/Shtypi/Pergiigija e Bankes se Shqiperise ndaj COVID-19/

10. AMF, Board Decision $7^{\text {th }}$ Apr, 2020

https://amf.gov.al/news.asp?id=32466

11. Aruna Polisetty, Indian MF during COVID pandemic times, 2020

https://www.researchgate.net/publication/343389834 Indian Mutual Funds during COVID pa ndemic times

12. AMF, Statistika TFI, 2020

https://amf.gov.al/statistika.asp?id=5\&s=2

13. Raiffeisen Invest Fund Data

https://www.raiffeisen-invest.al/sg/web/guest/investment-funds

14. WVP Fund Data

https://www.wvpfunds.al/wvp-top-invest

15. Credins Invest Fund Data

https://www.credinsinvest.com/performanca-e-fondit-credins-premium/

16. Albsig Invest Fund Data

https://www.albsiginvest.al/performanca-e-fondeve/

17. AMF, Periodic Report, Q4 2020

https://amf.gov.al/pdf/publikime/Fondelnvestimi31122020 1.xls

18. Bank of Albania, Interest Rates Report, 2021

https://www.bankofalbania.org/Tregjet/Normat e interesit/

19. Credins Invest Financial Statements

https://www.credinsinvest.com/raporte-financiare-fondin-e-investimit/

20. Raiffeisen Invest Financial Statements of Funds

https://www.raiffeisen-invest.al/sq/raportet-financiare 